\title{
DNA-BASED MOLECULAR IDENTIFICATION OF Urnula mediterranea (Ascomycota, Pezizales) COLLECTED IN CENTRAL SERBIA
}

\author{
Dejan D. Arsenijević ${ }^{\star 1}$, Stefan Z. Blagojević ${ }^{1}$, Nevena S. Planojević1, Aleksandra G. \\ Nikezić $^{1}$, Dejan S. Vidanović ${ }^{2}$ Nenad Milosavljević ${ }^{3}$, Snežana D. Marković ${ }^{1}$ \\ ${ }^{1}$ University of Kragujevac, Faculty of Science, Department for Biology and Ecology, \\ Radoja Domanovića 12, 34000 Kragujevac, Serbia \\ ${ }^{2}$ Veterinary Specialized Institute "Kraljevo", Žička 34, 36000 Kraljevo, Serbia \\ ${ }^{3}$ Ivana Milutinovića 23, 34000 Kragujevac, Serbia \\ *Corresponding author; E-mail: 5012-2019@pmf.kg.ac.rs
}

(Received March 4, 2021; Accepted April 12, 2021)

\begin{abstract}
Molecular systematics is a branch of systematics that analyzes genetic markers for the classification of organisms. Genetic markers include target sequences of molecules DNA, RNA, and amino acids. The most often used genetic markers are DNA markers, localized on DNA molecules. The study aim was DNA-based molecular identification of species Urnula mediterranea (M. Carbone, Agnello \& Baglivo) M. Carbone, Agnello \& P. Alvarado (2013), by using molecular systematics methods. This species was recently discovered for the first time in Central Serbia and determined only based on morphological characteristics. For the first time, U. mediterranea sampled in Serbia, was identified with DNA molecular markers. Extraction of DNA molecules was performed from the fruiting body of $U$. mediterranea. ITS region and the part of the gene for $28 \mathrm{~S}$ rRNA were amplified and sequenced by the Sanger method. Comparing the analyzed sequences with the sequences from the database, a match of $99.72 \%$ was found for the ITS region and $100 \%$ for the part of the gene for 28S rRNA. By molecular identification, it has been established that the sample belongs to the species $U$. mediterranea. Both analyzed DNA sequences of $U$. mediterranea were deposited into the NCBI database.
\end{abstract}

Keywords: Molecular systematics, DNA markers, Serbia, Urnula mediterranea.

\section{INTRODUCTION}

Molecular systematics is a scientific discipline that studies systematics and classification of organisms based on their phylogenetic relatedness determined by molecular analyses of genetic markers (MAURO and AGORRETA, 2010). Target sequences of amino acids, RNA molecules, and DNA molecules belong to the group of genetic markers. A molecular DNA marker is a nucleotide sequence with a known structure and exact location in the DNA molecule. DNA markers usually exist in a large number of copies, it can be very variable (high mutation rate) or conserved. Furthermore, they are usually highly polymorphic, 
which is why they provide more information than other sequences of the genome (NADEEM $e t$ al., 2018). Due to the advantages that characterize them, molecular DNA markers are most commonly used in the intraspecies and interspecies determination of phylogenetic relationships (PATWARDHAN et al., 2014; GROVER and SHARMA, 2016; NADEEM et al., 2018).

The most often analyzed genetic marker in the molecular taxonomy of fungi is the nuclear rRNA cistron. This marker includes genes for 18S rRNA, 5.8S rRNA, 28S rRNA as well as two Internal Transcribed Spacers (ITS1 and ITS2) (SCHOCH et al., 2012; CARBONE et al., 2013). Genes that encode 18S rRNA, 5.8S rRNA, and 28S rRNA are mainly used for the identification of species and determination of higher taxonomic categories as they are well conserved through generations. Otherwise, ITS1 and ITS2 are non-coding regions. They are highly variable and commonly used for fungal haplotyping. These regions are localized between previously mentioned rRNA genes in the genome (18S rRNA - ITS1 - 5.8S rRNA ITS2 - 28S rRNA) (BENALI et al., 2011; YANG et al., 2018). Analysis of molecular DNA markers includes reading their primary structure by sequencing methods (GRADA and WEINBRECHT, 2013). Furthermore, molecular identification, haplotype determination, and forming a phylogenetic tree are performed by comparing target sequences with available sequences in the databases.

Urnula mediterranea (M. Carbone, Agnello \& Baglivo) M. Carbone, Agnello \& P. Alvarado (2013) is naturally distributed in the Mediterranean climate. However, it was found and sampled in $2014^{\text {th }}$ for the first time on the territory of the Republic of Serbia (MilosaVlJeVić, 2017). The fruiting body of this fungus is round in the shape of a cup. The upper layer of the fruiting body is hymenial and dark red, the middle part is gelatinous consistency, and ocher-gray in color, while the lower layer is black. Flesh structure is odorless and tasteless. Previously, this species was determined only based on morphological characteristics.

The aim of this study was DNA-based molecular characterization of $U$. mediterranea species using molecular systematics methods. The final aim is to deposit all sequences in the NCBI base (National Center for Biotechnology Information).

\section{MATERIALS AND METHODS}

\section{Chemicals}

Tris (hydroxymethyl) aminomethane hydrochloride (Tris-HCl) was purchased from Alcaloid, Skopje. Sodium chloride $(\mathrm{NaCl})$ from Centrohem, Serbia. Ethylenediaminetetraacetic acid (EDTA), Cetrimonium Bromid Lysis Buffer (CTAB), Tris bases, Glacial Acetic Acid, distilled water, isopropanol, Ethidium bromide, Agarose, and Bromophenol blue from Sigma, USA. $\beta$-mercaptoethanol from Zorka Šabac, Serbia. Ethanol PCR grade from Vinex Etil, Serbia. Chloroform from Serva, Germany. Glycerol from LachNer, Czech Republic. DNeasy Blood \& tissue Kit from Thermo Fisher Scientific, USA. QIAGEN Multiplex PCR Kit from QIAGEN, Germany. GeneJET Gel Extraction Kit from Thermo Fisher Scientific, USA. Big Dye ${ }^{\mathrm{tm}}$ Terminator V3.1 Cycle Sequencing kit and BigDye XTerminator ${ }^{\text {tm }}$ Purification kit were purchased from Applied Biosystems, USA. All solvents and chemicals were of analytical grade. 


\section{Sampling and extraction of DNA from Urnula mediterranea}

The fungus Urnula mediterranea was sampled in Central Serbia, from the locality Žeželj (4358' 28.33" N, 2056' 53.54" E), near Kragujevac, in May 2018. The whole fruiting bodies were frozen at $-20^{\circ} \mathrm{C}$ and stored in the Laboratory for Cell and Molecular Biology, Faculty of Science, University of Kragujevac.

Extraction of DNA molecules from the fruiting body of the fungus was performed using the Cetrimonium Bromide Lysis Buffer, following the method described in detail in GARDES and BRUNS (1993). In the first step, $10 \mathrm{mg}$ of the sample was resuspended in $300 \mu \mathrm{l}$ CTAB buffer. The sample was incubated at $65^{\circ} \mathrm{C}$ then cooled down on ice alternately, for three times. In the next step, the sample was homogenized and incubated at $65^{\circ} \mathrm{C}$ for 60 minutes. DNA was precipitated and purified with chloroform, isopropanol, and $70 \%$ ethanol. The DNA pellet was dissolved in $100 \mu \mathrm{L}$ PCR grade water. The concentration and purity of extracted DNA were measured a spectrophotometer (Eppendorf BioPhotometer) on $\mathrm{A}_{260 / 280}$ $\mathrm{nm}$.

\section{PCR amplification}

QIAGEN Multiplex PCR Kit was used to amplify the target DNA sequences. The method was performed according to the manufacturer's instructions.

Two different sequences of the $U$. mediterranea genome were amplified: (a) region ITS1 - 5.8S rRNA - ITS2; (b) the part of the gene for 28S rRNA (Large SubUnite - LSU RNA). Both sequences are located within the nuclear genome. Primers used for amplification of two nuclear sequences are shown in Table 1 (CARBONE et al., 2013). The content of the PCR reaction mixture is shown in Table 2.

Table 1. Primers used for amplification of two nuclear sequences.

\begin{tabular}{c}
\hline ITS1 - 5.8S rRNA - ITS2 \\
\hline ITS1 F CTTGGTCATTTAGAGGAAGTAA \\
ITS4 R TCCTCCGCTTATTGATATGC \\
\hline The part of the gene for 28S rRNA \\
\hline LROR F ACCCGCTGAACTTAAGC \\
LR7 R TACTACCACCAAGATCT \\
\hline
\end{tabular}

Table 2. Basic components of PCR reaction mixture used to amplify the target sequences of the nuclear genome of $U$. mediterranea species.

\begin{tabular}{lcc}
\hline \multicolumn{1}{c}{ Concentration } & Volume $(\boldsymbol{\mu L})$ & Final conc. \\
\hline 2x QIAGEN Multiplex PCR Master Mix & 20 & $1 \mathrm{x}$ \\
10x PrimerMix, 5 $\boldsymbol{\mu M}$ (each) & $2.4($ each $)$ & $0.3 \mu \mathrm{M}$ \\
Genomic DNA & 2.1 & $20 \mathrm{ng}$ \\
Distilled water PCR grade & 15 & \\
\hline
\end{tabular}

Touch down program was used for PCR amplification of the nuclear region of $U$. mediterranea species. This program implies different annealing temperatures, as used primers had different melting temperatures (Tm). In the first step, initial denaturation on $95^{\circ} \mathrm{C}$ for 15 minutes was performed. Amplification was done in 40 cycles and consisted of three steps, denaturation $\left(94^{\circ} \mathrm{C}\right.$ for 30 seconds), annealing, and extension $\left(72^{\circ} \mathrm{C}, 45\right.$ seconds). The annealing temperature was decreasing for $0.5^{\circ} \mathrm{C}$ in the first 20 cycles (from $57^{\circ} \mathrm{C}$ to $47^{\circ} \mathrm{C}$ ), 
followed by 20 more cycles with constant annealing temperature $\left(47^{\circ} \mathrm{C}\right)$. At the end of the PCR reaction was a final extension on $72^{\circ} \mathrm{C}, 10$ minutes.

\section{Agarose gel electrophoresis}

For gel preparation 1.5\% agarose was resolved in TAE (Tris Acetate-EDTA) buffer ( $\mathrm{pH}$ 8.0, composed of Tris base, Glacial Acetic acid, EDTA, $\mathrm{dH}_{2} \mathrm{O}$ ) and added ethidium bromide. The function of ethidium bromide is binding for DNA and visualization of samples on a UV transilluminator. The sample was mixed with the 6x Simple Loading Buffer: bromophenol blue, $100 \%$ glycerol, and $\mathrm{dH}_{2} \mathrm{O}$. Amplified samples were separated using horizontal gel electrophoresis (BlueMarine ${ }^{\mathrm{tm}} 100$, Serva, Germany), on $100 \mathrm{~V}, 15-20$ minutes (LEE et al., 2012). The separated DNA fragments were visualized on a UV transilluminator (Vilber Lourmat, France).

\section{Sequencing of amplified DNA markers}

Sequencing was performed on an automatic capillary sequencer in Veterinary Specialized Institute Kraljevo, Kraljevo, Serbia. In the first step, the DNA samples were purified from the agarose gel, with the commercial purification GeneJET Gel Extraction Kit, following the manufacturer's instructions. The sequencing reaction was performed on Eppendorf mastercycler gradient PCR with Big Dye ${ }^{\mathrm{tm}}$ Terminator V3.1 Cycle Sequencing Kit. Two sequencing reactions were performed for each region, one with a forward primer $(\mathrm{F})$, and the other with a reverse primer $(\mathrm{R})$ to obtain more accurate results (Table 1). The components of sequencing reactions are shown in Table 3. Initial activation on $96^{\circ} \mathrm{C}$ for 1 minute, was the first step in the sequencing. Followed by 3 steps repeated in 25 cycles, denaturation on $96^{\circ} \mathrm{C}$ for 10 seconds, primer annealing on $50^{\circ} \mathrm{C}, 5$ seconds, and primer extension on $60^{\circ} \mathrm{C}, 4$ minutes.

After sequencing in a PCR, purification from free ddNTPs, primers, non-specific products and other residues is performed using the BigDye XTerminator ${ }^{\mathrm{tm}}$ Purification kit (Applied Biosystems, USA). The capillary electrophoresis was performed on 3130 Genetic Analyzer (Applied Biosystems, USA).

Table 3. The content of sequencing reaction mix with Big Dye ${ }^{\mathrm{tm}}$ Terminator V3.1

Cycle Sequencing kit.

\begin{tabular}{lcc}
\hline Components & U. mediterranea & T. thymallus \\
\hline Big Dye $^{\text {tm }}$ Terminator V3.1 Ready reaction & $4 \mu \mathrm{L}$ & $4 \mu \mathrm{L}$ \\
Big Dye $^{\text {tm }}$ Terminator V1.1 \& V3.1 5x & $2 \mu \mathrm{L}$ & $2 \mu \mathrm{L}$ \\
Sequencing buffer & $0.1 \mu \mathrm{L}$ & $0.1 \mu \mathrm{L}$ \\
Primer F & $0.1 \mu \mathrm{L}$ & $0.1 \mu \mathrm{L}$ \\
Primer R & $10 \mu \mathrm{L}$ & $10 \mu \mathrm{L}$ \\
Distilled water PCR grade & $4 \mu \mathrm{L}$ & $4 \mu \mathrm{L}$ \\
DNA sample & & \\
\hline
\end{tabular}

\section{Software analysis of amplified sequences}

The data obtained from the automatic sequencer were processed using two programs. Chromas Lite software, Version 2.6.6. (Technelysium Ltd.) was used for manual corrections of the obtained raw sequences. Mega 6 software (Molecular Evolutionary Genetics Analysis), Version 6.06., was used to align F (Forward) and R (Reverse) sequences and compare the difference between the two sequences to accurately identify nucleotide changes. Processed 
sequences are entered into the Nucleotide Blast program, which is available on the NCBI (https://blast.ncbi.nlm.nih.gov/Blast.cgi). Obtained sequences were compared with the sequences from the NCBI database in the Nucleotide Blast program.

\section{RESULTS}

\section{Yield and purity of genomic DNA from Urnula mediterranea}

Extraction of DNA molecules from the fruiting body of the fungus was performed using a CTAB buffer. This method provides a high yield of genomic DNA of $93.4 \mu \mathrm{g} / \mathrm{mL}$. However, the purity of isolated DNA was $1.21 \mathrm{~A}_{260 / 280}$. The purity was lower than optimal as it is considered that the optimal purity range is from 1.7 to $2.0 \mathrm{~A}_{260 / 280}$ (MEZzOMO et al., 2020).

\section{Agarose gel electrophoresis}

The success of PCR amplification was checked by agarose electrophoresis. Figure 1. indicates that the PCR amplification was successfully performed based on bands compared to the ladder. The amplified region ITS1 - 5.8S rRNA - ITS2 of species U. mediterranea was $800 \mathrm{bp}$, while the part of the gene for $28 \mathrm{~S}$ rRNA was $1500 \mathrm{bp}$. There were not non-specific products.

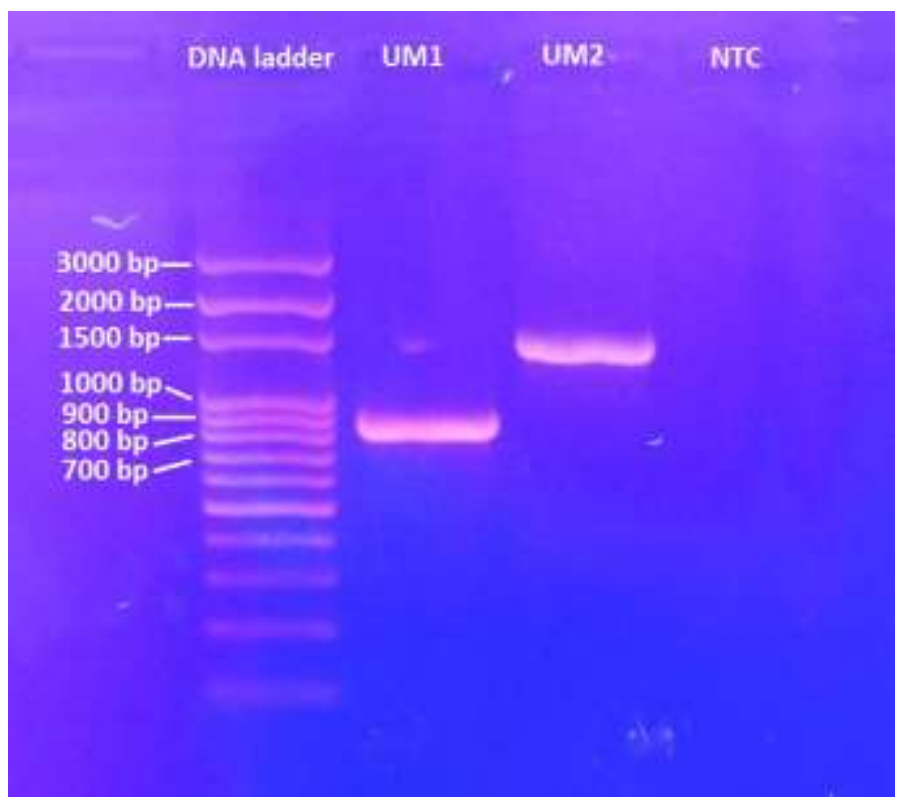

Figure 1. The results of the PCR products are shown on the $1.5 \%$ agarose gel.

UM1 - U. mediterranea (Region ITS1 - 5.8S rRNA - ITS2),

$\mathrm{UM} 2$ - U. mediterranea (the part of the gene for $28 \mathrm{~S}$ rRNA), NTC - No Template Control.

\section{Sequencing analysis of ITS1 - 5.8S rRNA gene - ITS2 region and part of the gene for 28S rRNA of Urnula mediterranea}

The primary structure of target regions was obtained by the sequencing process. The red color is the mark of Thymine, the blue color for Cytosine, the green color is the mark for the Adenine and the black color is the mark for the Guanine. All errors in sequence readings were manually corrected in Chromas Lite software. Those errors were unread nucleotides, double picks in one nucleotide position, or background noise. After the initial processing of 
amplified sequences of the $U$. mediterranea genome, the final lengths were $736 \mathrm{bp}$ and 784 bp, respectively (Figures 2 and 3).

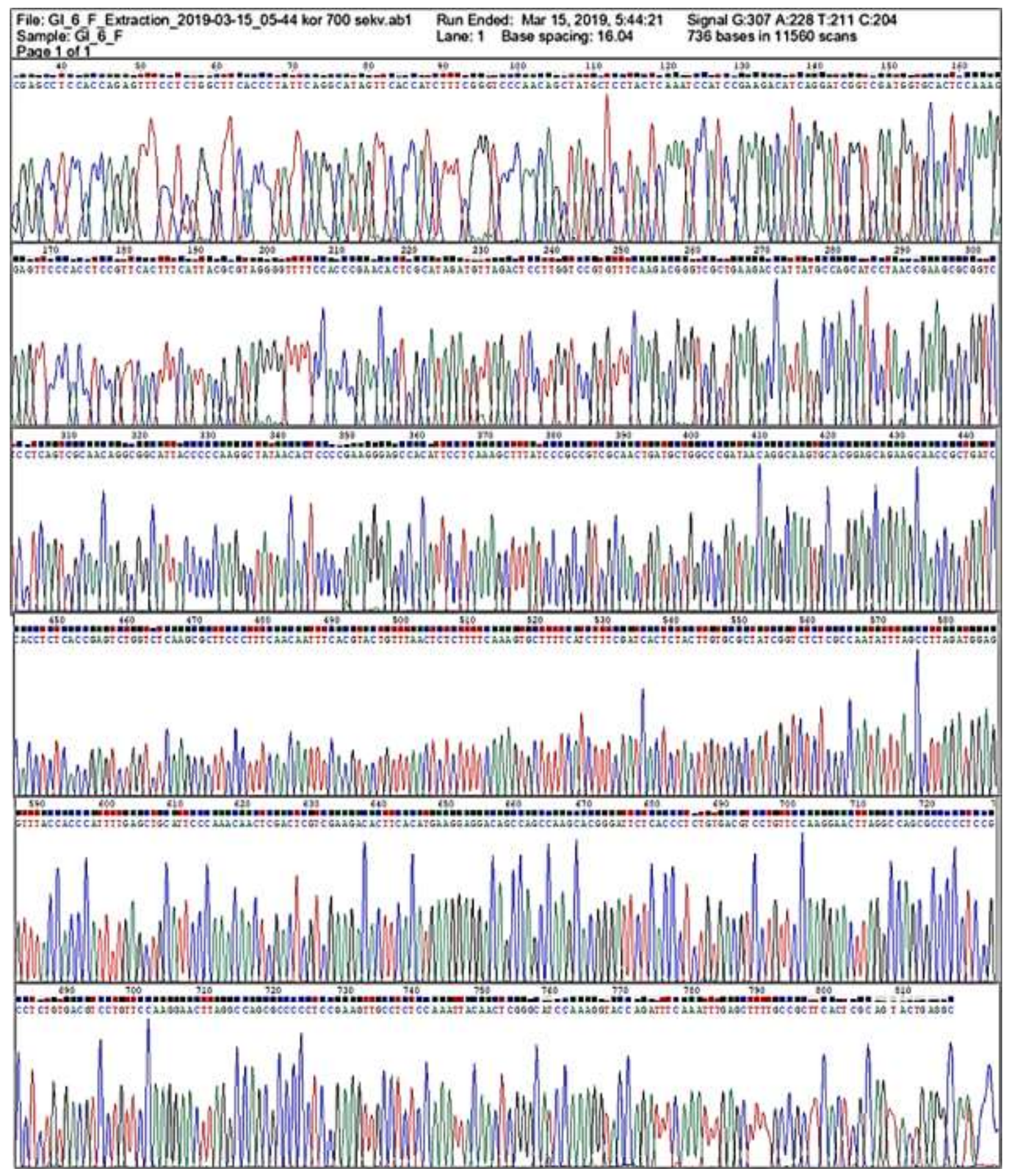

Figure 2. U. mediterranea. The result of sequenced region ITS1 - 5.8S rRNA - ITS2.

Analyzed sequences of $U$. mediterranea species were compared with sequences given in the NCBI database. It was determined that the ITS1 - 5.8S rRNA - ITS2 (Accession number: MW713112) of $U$. mediterranea species matches $99.72 \%$ with deposited NCBI sequences (Accession number: KU933925.1), while the analyzed part of the gene for 28S rRNA (Accession number: MW713113) matched a 100\% (Accession number: JX669864.1). Based on the analysis, the tested sample belongs to the species of $U$. mediterranea. The differences between analyzed sequences and sequences of the NCBI database are shown in Table 4. 


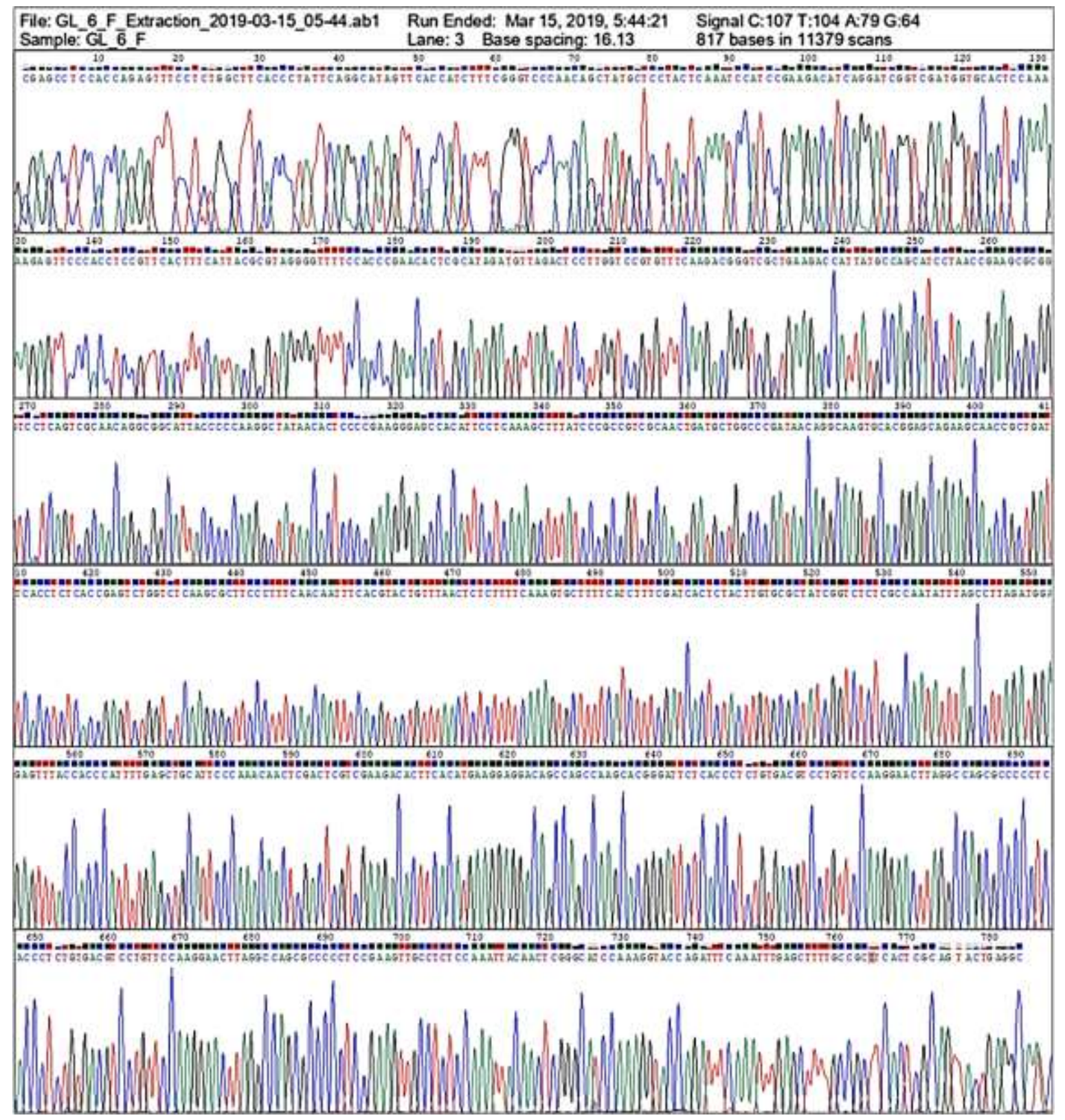

Figure 3. U. mediterranea. The part of the gene for $28 \mathrm{~S}$ rRNA.

Table 4. Representation of nucleotide differences between analyzed sequence ITS1 - 5.8S rRNA ITS2 and reference sequences deposited in the NCBI database for the species U. mediterranea.

\begin{tabular}{lcc}
\hline \multirow{2}{*}{ Nucleotide position } & $\begin{array}{c}\text { U. mediterranea } \\
\text { ITS1 - 5.8S rRNA - ITS2 }\end{array}$ & ITS1 - 5.8S rRNA - ITS2 \\
\hline 14 & $\mathrm{C}$ & $\mathrm{T}$ \\
322 & $\mathrm{C}$ & $\mathrm{T}$ \\
\hline
\end{tabular}

\section{DISCUSSION}

Molecular systematics has numerous advantages compared to the standard systematics approach. For instance, standard systematics is based only on the analysis of certain morphological characteristics. However, problems in species identification may occur with the appearance of sexual dimorphism, morphological form adult/larvae, and cryptic species. 
Molecular DNA markers are selected based on the type and aim of the study and are highly informative. Conserved DNA markers are usually used to identify species, while variable DNA markers are used to determine relationships between species. Those markers can be tracked in a small amount of starting material required to isolate optimal yield of DNA molecules (XIAO et al., 2010; GROVER and SHARMA, 2016). The focus of this research is whether the sampled fruiting body of the fungus belongs to the species $U$. mediterranea as it is morphologically determined, and to examine whether the sampled mushroom is an autochthonous or allochthones species on the territory of the Republic of Serbia.

The isolation of DNA molecules is one of the most important and sensitive steps in DNA marker analysis. Yield and purity of isolated DNA can significantly affect the success of amplification and further analysis (BOESENBERG-SMITH et al., 2012). CTAB method is selected because it effectively separates nucleic acids from polyphenol and other secondary metabolites from cells (UMESHA et al., 2016). Secondary metabolites are represented in large quantities in the fungi tissue (BILLS and GLOER, 2016). It is important to point out that in this research it was obtained high-quality DNA which can be used in downstream PCR and sequencing analysis.

For molecular identification of fungi, both the ITS region and the gene for 28S rRNA are most commonly analyzed. The ITS region contains conserved parts as well as highly variable regions. The gene for $28 \mathrm{~S}$ rRNA has informative D2 region that is analyzed in the molecular identification of the fungi. Unlike the gene for 18S rRNA, the gene for 28S rRNA is longer and can give us more information (SCHMIDT et al., 2006; SUBBOTIN et al., 2008; Gou et al., 2013). Optimal values of isolated DNA were obtained in this research as well. The amplification success and quality of DNA were checked by electrophoretic separation on an agarose gel. The amplification was performed successfully, without nonspecific products. Verifying amplification is a particularly important step in sequence analysis, due to the cost of chemicals used in the sequencing process.

Processing of raw sequences is performed in the Chromas lite program to correct misread parts of the sequences. By correcting poorly read sequences, misreading of the target DNA markers is avoided. The length of the sequenced part of the ITS1 - 5.8S rRNA - ITS2 region was $800 \mathrm{bp}$, while the $1500 \mathrm{bp}$ long sequence was used for 28S rRNA gene analysis. Both sequences ITS1 - 5.8S rRNA - ITS2 (Accesion number: MW713112) and the part of the gene for 28S rRNA (Accesion number: MW713113) were deposited in the NCBI database. So far, these two DNA markers have been sequenced and deposited for only a few specimens of $U$. mediterranea species.

Comparing the analyzed sequences with those from the database, a match of $99.72 \%$ was found for the ITS region and $100 \%$ for the part of the gene for $28 \mathrm{~S}$ rRNA, thus confirming that the sampled fungus belongs to the U. mediterranea species. In the territory of the Republic of Serbia, MilosaVlJEVIĆ (2017) identified U. mediterranea by the methods of standard systematics. In this study, the affiliation of sampled fungus to $U$. mediterranea species was confirmed with molecular markers. U. mediterranea is naturally distributed in the Mediterranean area of French, Greece, and Italy (CARBONE et al., 2013). However, $U$. mediterranea was found in atypical conditions, in the area of Continental Europe, assuming that one of the reasons can be climatic changes on this territory (MILOSAVLJEVIĆ, 2017). 


\section{CONCLUSION}

By molecular identification of fungus collected on Žeželj, near Kragujevac, in May $2018^{\text {th }}$, it has been confirmed that the first identification based on classical morphological characters was correct, i.e., sample belongs to $U$. mediterranea.

\section{Acknowledgments}

This study was supported by the Serbian Ministry of Education, Science and Technological Development (Projects no. III41010 until 2019 and Agreement No. 451-039/2021-14/200122).

\section{References:}

[1] Benali, S., Mohamed, B., Eddine, J.H., Neema, C. (2011): Advances of molecular markers application in plant pathology research. European Journal of Scientific Research 50 (1): 110-123.

[2] Bills, F.G., Gloer, B.J. (2016): Biologically active secondary metabolites from the fungi. Microbiol Spectrum 4 (6): 1-32. doi: 10.1128/microbiolspec.FUNK-0009-2016

[3] Boesenberg-Smith, A.K., Pessarakli, M.M., Wolk, M.D. (2012): Assessment of DNA Yield and Purity: an Overlooked Detail of PCR Troubleshooting. Clinical Microbiology Newsletter 34 (1): 1-6. doi: 10.1016/j.clinmicnews.2011.12.002

[4] Carbone, M., Agnello, C., Alvarado, P. (2013): Phylogenetic studies in the family Sarcosomatacea (Ascomycota, Pezizales). Ascomycete.org 5 (1): 1-12. doi: 10.25664/art-0075

[5] Gardes, M., BRUNS, T.D. (1993): ITS primers with enhanced specifity for basidiomycetes-application to the identification of mycorrhizae and rusts. Molecular Ecology 2: 113-118.

[6] Gou, H., Guan, G., Ma, M., Liu, A., Liu, Z., Xu, Z., Ren, Q., Li, Y., Yang, J., Chen, Z., YIN, H., LuO, J. (2013): Phylogenetic Analysis of Ruminant Theileria spp. from China Based on 28S Ribosomal RNA Gene. Korean Journal of Parasitology 51 (5): 511-517. doi: 10.3347/kjp.2013.51.5.511

[7] Grada, A., Weinbrecht, K. (2013): Next-Generation Sequencing: Methodology and Application. Journal of Investigative Dermatology 133: 1-4. doi: 10.1038/jid.2013.248

[8] Grover, A., Sharma, C.P. (2016): Development and use of molecular markers: past and present. Critical Reviews in Biotechnology 36 (2): 290-302. doi: 10.3109/07388551.2014.959891

[9] Lee, Y.P., Costumbrado, J., Hsu, C.Y., KiM, Y.H. (2012): Agarose gel electrophoresis for the separation of DNA fragments. Journal of Visualized Experiments 62: 1-5. doi: $10.3791 / 3923$

[10] Mauro, S.D., Agorreta, A. (2010): Molecular systematics: A synthesis of the common methods and the state of knowladge. Cellular \& molecular biology letters 15: 311-341. doi: 10.2478/s11658-010-0010-8

[11] Mezzomo, P., Mielniczki-Pereira, A.A., Sausen, T.L., Marinho, R.J., Cansian, L.R. (2020): Evaluation of eight protocols for genomic DNA extraction of Hypostomus 
commersoni Valenciennes, 1836 (Loricariidae: Siluriformes). Brazilian Journal of Biology 81 (3): 674-683. doi: 10.1590/1519-6984.229278

[12] Milosavljević, N. (2017): The first record of Urnula mediterranea (Pezizales) in Continental Europe. Ascomycete.org 9 (5): 156-163.

[13] NadeEm, A.M., Nawaz, A.M., Shahid, Q.M., DoĞan, Y., Comertay, G., Yildiz, M., Ahmat, F.H.R., Alsaleh, A., Labhane, N., Özkan, H., Chung, G., Baloch, S.F. (2018): DNA molecular markers in plant breeding: current status and recent advancements in genomic selection and genome editing. Biotechnology \& Biotechnological Equipment, 32 (2): 261-285. doi: 10.1080/13102818.2017.1400401

[14] Patwardhan, A., Ray, S., Roy, A. (2014): Molecular Markers in Phylogenetic Studies-A Review. Journal of Phylogenetics \& Evolutionary Biology 2 (131): 1-9. doi: 10.4172/2329-9002.1000131

[15] SCHMidT, S., DRIVER, F., BARRO, P.D. (2006): The phylogenetic characteristics of three different 28S rRNA gene regions in Encarsia (Insecta, Hymenoptera, Aphelinidae). Organism Diversity and Evolution 6: 127-139. doi: 10.1016/j.ode.2005.07.002

[16] Schoch, L.C., Seifert, A.K., Huhndorf, S., Robert, V., Spouge, L.J., Levesques, A.C., Chen, W., Fungal BarCoding Consortium. (2012): Nuclear ribosomal internal transcribed spacer (ITS) region as a universal DNA barcode marker for Fungi. Proceedings of the National Academy of Sciences of the United States of America 109 (16): 6241-6246. doi: 10.1073/pnas.1117018109

[17] Subbotin, S.A., Ragsdale, E.J., Mullens, T., Roberts, P.A., Mundo-Ocampo, M., BALDWIN, J.G. (2008): A phylogenetic framework for root lesion nematodes of the genus Pratylenchus (Nematoda): Evidence from 18S and D2-D3 expansion segments of 28S ribosomal RNA genes and morphological characters. Molecular Phylogeneti Evolution 48: 491-505. doi: 10.1016/j.ympev.2008.04.028

[18] Umesha S., MANukumar, M.H., Raghava, S. (2016). A rapid method for isolation of genomic DNA from food-borne fungal pathogens. 3 Biotech 6(123): 1-9. doi: 10.1007/s13205-016-0436-4

[19] XiaO, J.H., Wang, N.X., LI, Y.W., MurPhy, R. W., Wan, D.G., Niu, L.M., Hu, H. J., Fu, J.G., HuAnG, D.W. (2010): Molecular Approaches to Identify Cryptic Species and Polymorphic Species within a Complex Community of Fig Wasps. PLoS ONE 5 (11): e15067. doi: 10.1371/journal.pone.0015067

[20] Yang, H.R., Su, H.J., Shang, J.J., Wu, Y.Y., LI, Y., BAO, P.D., YAO, J.Y. (2018): Evaluation of the ribosomal DNA internal transcribed spacer (ITS), specifically ITS1 and ITS2, for the analysis of fungal diversity by deep sequencing. PLOS One 13 (10): 117. doi: 10.1371 /journal.pone. 0206428 